\title{
A proteomics study of colostrum and milk from the two major small ruminant dairy breeds from the Canary Islands: a bovine milk comparison perspective
}

\author{
Lorenzo E. Hernández-Castellano ${ }^{1,2}$, André M. Almeida ${ }^{3,4,5}$, Jenny Renaut ${ }^{6}$, Anastasio Argüello ${ }^{1}$ and \\ Noemí Castro ${ }^{1 *}$ \\ 'Animal Production and Biotechnology group, Institute of Animal Health and Food Safety, Universidad de Las Palmas de Gran Canaria, \\ Arucas, Gran Canaria, Spain \\ ${ }^{2}$ Veterinary Physiology, Vetsuisse Faculty, University of Bern, Bern, Switzerland \\ ${ }^{3}$ CIISA - Centro de Investigação Interdisciplinar em Sanidade Animal \& IICT - Instituto de Investigação Científica Tropical, Centro de \\ Veterinária e Zootecnia, FMV, Lisboa, Portugal \\ ${ }^{4}$ IBET - Instituto de Biologia Tecnológica e Experimental, \& ITQB/UNL - Instituto de Tecnologia Química e Biológica António Xavier da \\ Universidade Nova de Lisboa, Oeiras, Portugal \\ ${ }^{5}$ Ross University School of Veterinary Medicine, Basseterre, St. Kitts and Nevis, West Indies \\ ${ }^{6}$ Environmental Research and Innovation (ERIN) Department, Luxembourg Institute of Science and Technology (LIST), Esch/Alzette, \\ Luxembourg
}

Received 9 November 2015; accepted for publication 19 April 2016

Colostrum and milk feeding are key factors for the newborn ruminant survival, affecting the future performance of the animal. Nowadays, there is an increasing interest in the potential of feeding newborn ruminants (mainly goat kids and lambs) with colostrum and milk from other more productive ruminant species (mainly cows). Although some studies regarding differences between colostrum and milk from these three species have been performed, herein we conduct for the first time a comparison using a proteomics 2-Dimensional Electrophoresis gel-based approach between these three ruminant species. In this study colostrum and milk samples from six Holstein cows, six Canarian sheep and six Majorera goats were used to determine the chemical composition, immunoglobulin G (IgG) and M (IgM) concentrations and proteomics profiles. Results showed that in general sheep colostrum and milk contained higher fat, protein and lactose percentages compared to bovine and goat samples. Additionally, no differences in the $\operatorname{lgG}$ or $\lg M$ concentrations were found among any of the three studied species, with the exception of sheep colostrum that showed the highest IgM concentration. With reference to the proteomics-based approach, some high abundant proteins such as serum albumin precursor, beta-caseins or different immunoglobulins components were found in colostrum, milk or even both. Nevertheless, differences in other proteins with immune function such as serotransferrin or lactoperoxidase were detected. This study shows that despite the similar immunoglobulin concentrations in colostrum and milk from the three studied species, differences in several immune components can be detected when these samples are studied using a proteomics approach. Finally, this study also provides a base for future investigation in colostrum and milk proteomics and metabolomics.

Keywords: proteomics, colostrum, milk, small ruminants, immune.

Colostrum is the first secretion from the mammary gland after parturition and it starts changing after birth, becoming mature milk (Hernández-Castellano et al. 2014a; Lérias

*For correspondence; e-mail: noemi.castro@ulpgc.es et al. 2014). Colostrum feeding in mammals is very important to provide protection (passive immune transfer, PIT) against infections in newborn mammals (CzesnikiewiczGuzik et al. 2007a; Castro et al. 2011; HernándezCastellano et al. 2015a). The interest for heterologous PIT such as immunoglobulins (Ig) obtained from one species and utilised for passive immunity in other species is 
increasing worldwide (Hurley \& Theil, 2011; HernándezCastellano et al. 2015b). This tendency is extended in orphan ruminants, because the homology between cattle, goats and sheep Ig ensures a biological activity of these macromolecules in the different species (Curtain \& Fudenber, 1973). Additionally, this method can also be used in those born from dams with inadequate colostrum, or those not allowed to suckle their dams (MoralesdelaNuez et al. 2011), where an alternative source of colostrum or commercially available colostrum substitute is used (Tsiligianni et al. 2012). Despite the importance of colostrum in newborn survival, differences in milk composition can also have severe consequences in newborn ruminants. In dairy intensive systems, such as those found throughout the Canary Islands, newborn ruminants are separated from dams and fed with a milk replacer or another milk source (Hernández-Castellano et al. 2015c). As described above, milk composition is an important aspect as a non-balanced feeding source may affect animal performance in young ruminants (Hernández-Castellano et al., 2013a, b) with severe consequence for animal welfare. Therefore, further research focus on differences within colostrums and milks from different ruminant species is required. We hypothesise that even though some differences between colostrum and milk from different ruminant species has already been described, the use of proteomics, based on 2D-gel electrophoresis, complemented with traditional methods based on gross chemical composition (fat, protein, lactose, dry matter percentage and immunoglobulin concentration) will provide further information about these two fluids from the two most relevant ruminant species dairy breeds in the Canary Islands, the Canarian sheep and the Majorera goat (Lérias et al. 2013; Hernández-Castellano et al. 2014a). In order to obtain a comparison term, we have also contrasted the results for each fluid to those of colostrum and milk of the most widely found dairy ruminant species and breed across the globe: the Holstein cow.

\section{Material and methods}

Spanish and European Union guidelines and legislation on care, use and handling of experimental farm animals were followed. All samples (colostrum and milk) used in this study were obtained at the milking parlour after animals were completely milked. This study did not involve any capture of live animals or animal experimentation, thus no specific ethical approval was necessary. During the experimental period, animals were under veterinary supervision. Animal health status was monitored (for diarrhoea, mastitis or fever) and they were found to be healthy throughout the experimental period.

\section{Sample collection}

Six Holstein cows, six Canarian sheep and six Majorera goats in their second lactation were used in this experiment.
Animals were fed following recommendations of the Institut National de la Recherche Agronomique (INRA, 2007). The experiment took place at the experimental farm of the Veterinary Faculty of the Universidad de Las Palmas de Gran Canaria (Canary Islands, $28^{\circ} 8^{\prime} 20 \cdot 66^{\prime \prime} \mathrm{N}, 15^{\circ} 30^{\prime}$ $24 \cdot 97^{\prime \prime}$, Spain) during spring. Colostrum samples (20 ml) from the whole available colostrum were individually taken immediately after parturition in the three studied species. Similarly, milk samples $(20 \mathrm{ml})$ were individually collected $20 \mathrm{~d}$ after parturition. Both colostrum and milk samples were frozen $\left(-80^{\circ} \mathrm{C}\right)$ until further analysis.

\section{Sample treatment for analysis}

Colostrum and milk samples $(10 \mathrm{ml}$ each) were centrifuged following the procedure described by Boehmer et al. (2008). In this procedure samples were centrifuged at $44000 \times \mathbf{g}$ at $4{ }^{\circ} \mathrm{C}$ for $30 \mathrm{~min}$, and the fat layer was removed with a spatula. The skimmed milk was decanted into a clean tube, centrifuged at $44000 \times \mathbf{g}$ at $4{ }^{\circ} \mathrm{C}$ for $30 \mathrm{~min}$ and the translucent supernatant (whey fraction) was collected and stored at $-80^{\circ} \mathrm{C}$. Caseins have been the principle target of high-abundance protein removal in sample preparation of milk from healthy cows.

\section{Chemical composition and Ig concentration}

Fat, protein, lactose and total solids contents of different colostrum and milk samples (as well as their respective whey fractions) were determined by routine laboratory procedures using an automated infrared method with a DMA2001 Milk Analyser (Miris Inc., Uppsala, Sweden). Quantification of Ig in colostrum and milk (and their respective whey fractions) were performed using IgG and IgM ELISA kits (Bethyl Laboratories, Montgomery, TX, USA).

Differences in chemical composition and Ig concentration within colostrum, milk, colostrum whey and milk whey from goat, sheep and cow were analysed using the ANOVA procedure of SAS (Version 9.0, Institute Inc., Cary, NC, USA). Results were expressed as mean \pm SD. Significant differences required $P<0.05$ for all measured parameters.

\section{Two-dimensional gel electrophoresis (2DE)}

Samples from colostrum and milk whey fractions were desalted with ReadyPrep 2D-Clean-up kit (Biorad, Hercules, CA, USA). The protein concentration of these samples was subsequently determined using the Quick Start Protein Assay kit (Biorad, Hercules, CA, USA), setting bovine gammaglobulin as a standard (Biorad, Hercules, CA, USA). Then, every whey protein sample $(400 \mu \mathrm{g})$ was diluted in rehydration buffer (8 M urea, 2\% (w/v) 3-[(3-Cholamidopropyl) dimethylammonio]-1-propanesulfonate (CHAPS), $50 \mathrm{mM}$ dithiothreitol, $0 \cdot 2 \%(\mathrm{w} / \mathrm{v})$ BioLyte 3/10 ampholyte, $0.002 \%(\mathrm{w} / \mathrm{v})$ bromophenol Blue)) to a final sample volume of $300 \mu \mathrm{l}$. After dilution in rehydration buffer, samples were applied to 


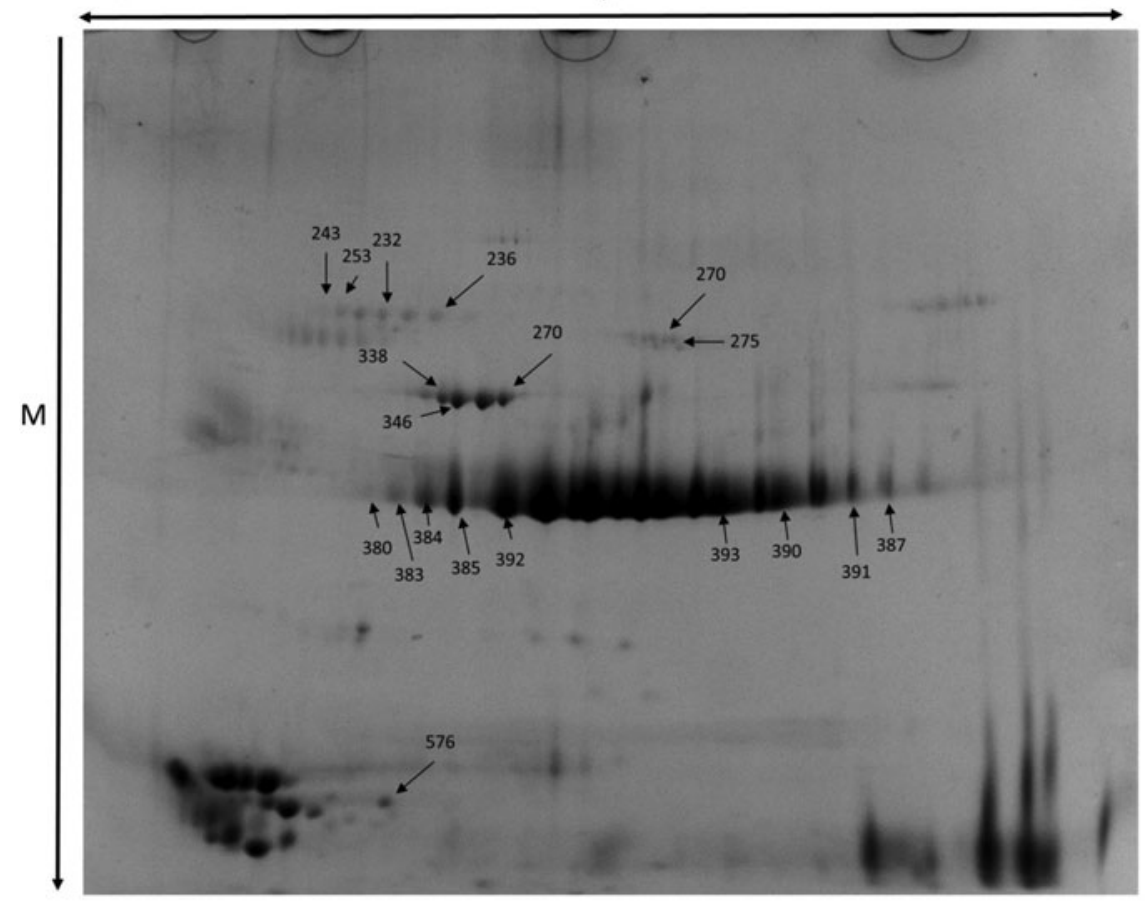

Fig. 1. Colostrum reference gel. Spots showing differential expression are highlighted with arrows. pl, Isoelectric point and M, Molecular Mass.

17-cm pH 3-10 nonlinear immobilised $\mathrm{pH}$ gradient (IPG) strips (Biorad, Hercules, CA, USA) and focused in a Bio-Rad Protean IEF Cell for $20 \mathrm{~h}$ using the following voltage intervals: $500 \mathrm{~V}$ for $1 \mathrm{~h}, 1000 \mathrm{~V}$ for $1 \mathrm{~h}, 2000 \mathrm{~V}$ for $2 \mathrm{~h}, 4000 \mathrm{~V}$ for $4 \mathrm{~h}$, and $8000 \mathrm{~V}$ for $12 \mathrm{~h}$, as described by Boehmer et al. (2008).

Subsequently, strips were equilibrated with equilibration buffer $(6 \mathrm{M}$ urea, $2 \%(\mathrm{w} / \mathrm{v}) \mathrm{SDS}, 50 \mathrm{mM}$ Tris-HCl pH 8.8, $30 \%(\mathrm{v} / \mathrm{v})$ glycerol and $0.02 \%$ bromophenol blue solution $(1 \%))$, in two steps of $15 \mathrm{~min}$ with $1 \%(\mathrm{w} / \mathrm{v})$ dithiothreitol and $2.5 \%(\mathrm{w} / \mathrm{v})$ iodoacetamide, respectively as previously described by Almeida et al. (2010).

Second dimension was conducted after equilibration using $12 \cdot 5 \%$ polyacrylamide gels on a Protean II xi Cell electrophoresis system (Biorad, Hercules, CA, USA) using the running conditions as recommended by the manufacturer $\left(1 \mathrm{~W} /\right.$ gel for $1 \mathrm{~h}$ and $2 \mathrm{~W} /$ gel for $14-16 \mathrm{~h}$ at $\left.12{ }^{\circ} \mathrm{C}\right)$. Each gel was stained using Coomassie Brillant Blue G-250 as previously described by Almeida et al. (2010) and scanned with a Gel Doc XR system (Biorad, Hercules, CA, USA).

\section{Image analysis}

In order to detect differentially expressed proteins, gels were analysed using Progenesis SameSpots software (Nonlinear Dynamics, Newcastle upon Tyne, UK). Spots with $P<$ 0.05 and a fold intensity higher than 1.5 were considered to have significantly different expression levels.

\section{Spot excision and digestion}

Protein spots of interest (Figures 1 and 2) were excised from the gel with a sterile $1000 \mu \mathrm{l}$ pipette tip or a sterile stainless scalpel blade for individual in-gel digestion using trypsin as described by Almeida et al. (2010). Briefly, spots were washed with $30 \mu \mathrm{l}$ of water for $30 \mathrm{~min}$, washed in acetonitrile $(50 \%)$, reduced with $10 \mathrm{mM}$ dithiothreitol at $56^{\circ} \mathrm{C}$ for $45 \mathrm{~min}$, alkylated with $55 \mathrm{mM}$ iodoacetamide for 30 min, washed in acetonitrile $(100 \%)$ and vacuum dried

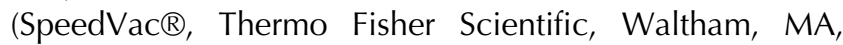
USA). Gel pieces were rehydrated with a digestion buffer $(50 \mathrm{mM} \mathrm{NH} 4 \mathrm{HCO} 3$ buffer) containing $50 \mu \mathrm{l}$ of trypsin $(6.7 \mathrm{ng} / \mu \mathrm{l}$; Promega, Madison, WI, USA) and incubated overnight at $37^{\circ} \mathrm{C}$. The digestion buffer containing the peptides was acidified with formic acid, desalted and concentrated using C8 microcolumns (POROS R2 ${ }^{\circledR}$, Applied Biosystems, Foster City, CA, USA), as described by Almeida et al. (2010).

\section{Protein identification}

Protein identification was conducted as described by Printz et al. (2013). Briefly, peptide mass determinations were carried out using the 5800 Proteomics Analyser (ABsciex) in reflectron mode for both peptide mass fingerprint and MS/MS. Calibration was performed with the peptide mass calibration kit for 4700 (ABsciex). Protein identification 


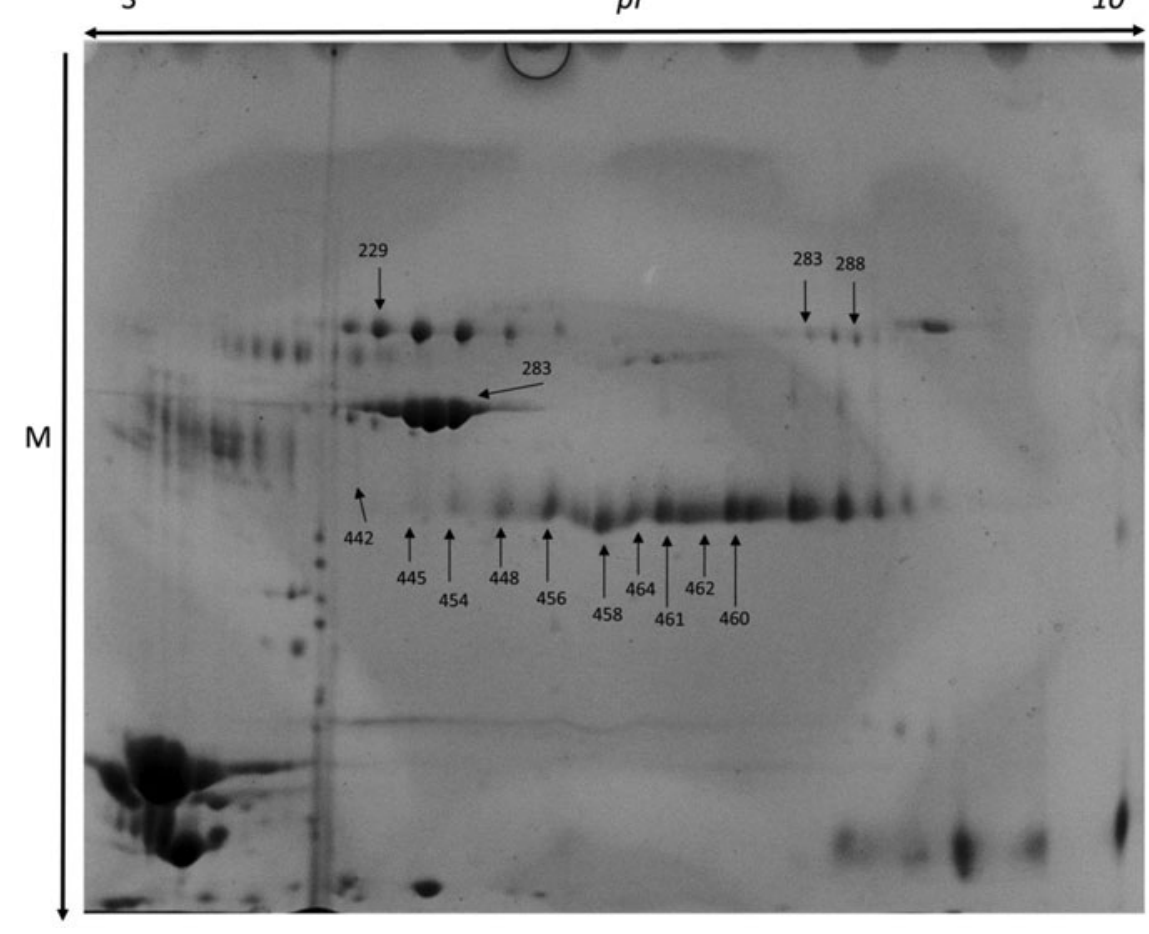

Fig. 2. Milk reference gel. Spots showing differential expression are highlighted with arrows. pl, Isoelectric point and M, Molecular Mass.

was done by searching the MS and MS/MS data against $\mathrm{NCBI}$ database in the Other Mammalia taxonomy (434 586 sequences), using an in house MASCOT 2.3 server (www.matrixscience.com). Two trypsin missed cleavages, four dynamic modifications (methionine and tryptophan oxidation, tryptophan dioxydation and tryptophan to kynurenin), and carbamidomethylation of cysteine as fixed modification were allowed. Mass accuracy was set to 100 ppm for parent ions and 0.5 Da for MS/MS fragments. Homology identification was retained with probability set at $95 \%$. All identifications were confirmed manually.

\section{Results and discussion}

\section{Chemical composition}

Table 1 shows the chemical composition and Ig concentration of goat, sheep and cow colostrum and milk. As expected, fat percentage was lower in cow colostrum $(6 \cdot 66 \%)$ than those measured in goats and sheep (9.06 and $9.94 \%$, respectively). Similarly, the fat percentage in cow milk was lower $(3 \cdot 26 \%)$ compared to goat or sheep milk (4.47 and $6.39 \%$, respectively). No differences were detected when sheep and goat colostrum were compared, although sheep showed higher milk fat percentage. Results described above are in accordance with previous studies in these three different species. Abd ElFattah et al. (2012) described similar milk fat percentages in Holstein cows to those presented in this study $(4.00$ and $3 \cdot 26 \%$, respectively), although these authors observed higher fat percentage in colostrum (8.04\%). Similarly, Moreno-Indias et al. (2012) and Banchero et al. (2004) showed similar fat percentages in Majorera goat colostrum $(8 \cdot 70 \%)$ and Corriedale sheep colostrum $(10 \cdot 60 \%)$, respectively. Additionally, Álvarez et al. (2007) and James et al. (2001) found similar fat percentages to those reported in this study in Majorera goat milk $(4 \cdot 39 \%)$ and Lacaune sheep milk $(6 \cdot 86 \%)$, respectively.

Some differences in colostrum and milk protein percentages were also detected among the studied species. Sheep colostrum showed higher protein percentage than goat colostrum (13.94 and $10 \cdot 16 \%$, respectively). No differences were observed when goat or sheep colostrum was compared to bovine colostrum. Conversely, when these differences were studied in milk, sheep obtained the highest protein percentage $(6 \cdot 60 \%)$. This study shows lower values in colostrum protein percentages compared to other studies in Holstein cows (Abd El-Fattah et al. 2012), Majorera goats (MorenoIndias et al. 2012) and Corriedale sheep (Banchero et al. 2004), although milk protein percentages were similar to those described in other studies (Park et al. 2007; Abd ElFattah et al. 2012; Torres et al. 2013).

No differences in the lactose percentage in colostrum between studied species were detected. Nevertheless, sheep milk had a higher lactose percentage $(5 \cdot 75 \%)$ than cow or goat milk (4.35 and $4 \cdot 17 \%$, respectively). Similar values were observed by Abd El-Fattah et al. (2012) in Holstein cow colostrum and milk. Additionally, MorenoIndias et al. (2012) and Banchero et al. (2006) found 


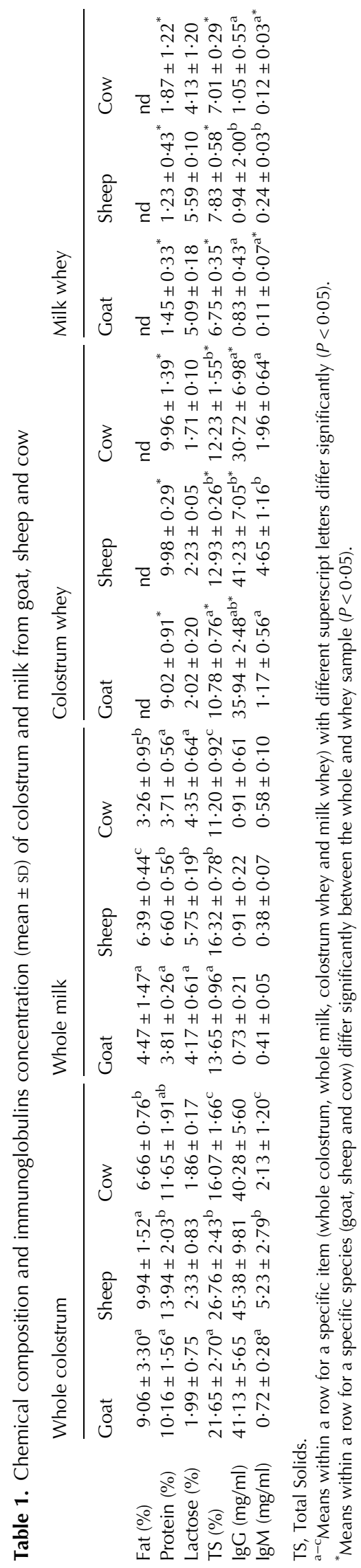

similar values to those shown in this study, in Majorera goat and Corriedale sheep colostrum, respectively.

As can be observed in Table 1, sheep colostrum and milk usually contained higher percentages of protein, fat and lactose than those from goat and cow. As a result, the total solid percentage observed in colostrum and milk from sheep was also higher than those from goat and cow.

\section{Ig concentration}

No differences in the IgG concentration were observed in colostrum or milk from the three studied species. In accordance to these findings, Stelwagen et al. (2009); Moreno-Indias et al. (2012) and Tabatabaei et al. (2013) found similar IgG concentrations in colostrum from Holstein cows (47.60 $\mathrm{mg} / \mathrm{ml})$, Majorera goats $(41.20 \mathrm{mg} / \mathrm{ml})$ and Lori Bakhtiyari sheep $(52.62 \mathrm{mg} / \mathrm{ml})$, respectively. Similarly, no differences were detected regarding IgM concentration in milk from the different studied species, although sheep colostrum showed higher values $(5 \cdot 23 \mathrm{mg} / \mathrm{ml})$ than cows and goats, being the goat colostrum the one that obtained the lowest IgM concentration in this study $(0.72 \mathrm{mg} / \mathrm{ml})$. Similar IgM concentration was described by Hernández-Castellano et al. (2015d) in colostrum from the same breed of sheep $(5.61 \mathrm{mg} / \mathrm{ml})$.

\section{Colostrum and milk proteomics}

As described above, there is a considerable interest in the potential for heterologous PIT, such as Ig obtained from one species and utilised for passive immunity in another species (Hurley \& Theil, 2011). Traditional methods based on gross chemical composition (fat, protein, lactose and dry matter percentage) or even on Ig concentration are frequently used for colostrum or milk characterisation. However, they are not thorough enough to fully describe differences between colostrum and milk from different ruminant species. Because of the wide range of protein concentrations and subcellular locations present in colostrum and milk, samples need to be processed before running any type of proteomics approach (Hernández-Castellano et al. 2014b; Zhang et al. 2015). According to the results shown in Table 1, protein and total solids percentages, as well as IgG and IgM concentration were slightly affected by the centrifugation process. In contrast, lactose percentage was not affected by the centrifugation process.

The differentially expressed proteins identified in colostrum whey from the three studied ruminant species are shown in Table 2. In contrast to the results showed in Table 1 about IgG and IgM concentration in colostrum whey, most of the differences between species were based on the several immune components, such as the Ig heavy chain $\mathrm{C}$ region, immunoglobulin gamma 2 heavy chain constant region, Ig gamma-1 chain, polymeric immunoglobulin receptor isoform 1 and the immunoglobulin mu heavy chain constant region. The differences between the proteomics results and the ELISA-based results could be 
Table 2. Spots showing differential expression between goat, sheep and cow colostrum whey samples $(P<0 \cdot 05$ and fold change $>1 \cdot 5)$

\begin{tabular}{|c|c|c|c|c|c|c|c|c|c|c|c|c|c|}
\hline \multirow[b]{2}{*}{ Spot } & \multirow[b]{2}{*}{$P$-value } & \multirow[b]{2}{*}{ Fold } & \multicolumn{3}{|c|}{$\begin{array}{l}\text { Average normalised } \\
\text { volumes }\left(\mathrm{E}^{+06}\right)\end{array}$} & \multirow[b]{2}{*}{ Protein name } & \multirow{2}{*}{$\begin{array}{l}\text { Accession } \\
\text { number }\end{array}$} & \multirow{2}{*}{$\begin{array}{l}\text { Theoretical } \\
\text { molecular } \\
\text { mass (kDa) }\end{array}$} & \multirow[b]{2}{*}{ Theoretical PI } & \multicolumn{2}{|c|}{$\begin{array}{l}\text { Matched } \\
\text { peptides } \dagger\end{array}$} & \multirow{2}{*}{$\begin{array}{l}\text { Sequence } \\
\text { coverage }(\%) \dagger\end{array}$} & \multirow[b]{2}{*}{ Protein score§ } \\
\hline & & & Goat & Sheep & Cow & & & & & MS & MS/MS & & \\
\hline 232 & $0 \cdot 020$ & 1.9 & $6 \cdot 01$ & $11 \cdot 50$ & $9 \cdot 05$ & Ig heavy chain $\mathrm{C}$ region & gi|109029 & 34327 & $6 \cdot 07$ & 15 & 5 & 36 & 274 \\
\hline 236 & $0 \cdot 003$ & 1.9 & $4 \cdot 00$ & $7 \cdot 11$ & $3 \cdot 74$ & Albumin precursor & gi|193085052 & 68266 & $5 \cdot 58$ & 17 & 6 & 21 & 428 \\
\hline 243 & $0 \cdot 017$ & $2 \cdot 6$ & $6 \cdot 71$ & $9 \cdot 93$ & $17 \cdot 50$ & Albumin precursor & gi|193085052 & 68266 & $5 \cdot 58$ & 24 & 2 & 33 & 132 \\
\hline 253 & $0 \cdot 011$ & $2 \cdot 9$ & $6 \cdot 28$ & $1 \cdot 11$ & $18 \cdot 10$ & $\begin{array}{l}\text { Immunoglobulin gamma } 2 \text { heavy } \\
\text { chain constant region }\end{array}$ & gi|147744654 & 21648 & $6 \cdot 33$ & 16 & 3 & 50 & 293 \\
\hline 270 & $0 \cdot 008$ & 1.9 & $1 \cdot 36$ & $1 \cdot 29$ & $24 \cdot 40$ & Ig heavy chain $\mathrm{C}$ region & gi|109029 & 34327 & $6 \cdot 07$ & 17 & 5 & 40 & 453 \\
\hline 275 & $0 \cdot 002$ & $2 \cdot 8$ & $0 \cdot 13$ & $0 \cdot 80$ & $2 \cdot 22$ & Serum albumin precursor & gi|57164373 & 71139 & $5 \cdot 8$ & 18 & 5 & 23 & 376 \\
\hline 338 & $<0 \cdot 001$ & $3 \cdot 3$ & $10 \cdot 10$ & $13 \cdot 70$ & $4 \cdot 20$ & $\begin{array}{l}\text { Immunoglobulin gamma } 2 \text { heavy } \\
\text { chain constant region }\end{array}$ & gi|147744654 & 21648 & $6 \cdot 33$ & 12 & 3 & 43 & 239 \\
\hline 346 & $<0 \cdot 001$ & $3 \cdot 4$ & $7 \cdot 45$ & $13 \cdot 00$ & $3 \cdot 86$ & Ig heavy chain $\mathrm{C}$ region & gi|109029 & 34327 & $6 \cdot 07$ & 16 & 4 & 40 & 285 \\
\hline 351 & $<0 \cdot 001$ & $2 \cdot 8$ & $14 \cdot 80$ & $35 \cdot 30$ & $12 \cdot 40$ & Serotransferrin & gi| 2501351 & 79870 & $6 \cdot 75$ & 25 & 3 & 39 & 291 \\
\hline 380 & $<0 \cdot 001$ & $3 \cdot 2$ & $8 \cdot 25$ & $13 \cdot 40$ & $26 \cdot 60$ & Ig heavy chain $\mathrm{C}$ region & gi| 109029 & 34327 & $6 \cdot 07$ & 15 & 5 & 36 & 491 \\
\hline 383 & $<0 \cdot 001$ & $2 \cdot 6$ & $10 \cdot 80$ & $15 \cdot 40$ & $27 \cdot 80$ & Ig gamma- 1 chain & gi|346578 & 52218 & $5 \cdot 65$ & 15 & 4 & 23 & 230 \\
\hline 384 & $0 \cdot 002$ & $2 \cdot 0$ & $16 \cdot 00$ & $19 \cdot 60$ & $31 \cdot 40$ & $\begin{array}{l}\text { Polymeric immunoglobulin re- } \\
\text { ceptor isoform } 1\end{array}$ & gi|426239425 & 83669 & $5 \cdot 79$ & 29 & 6 & 31 & 599 \\
\hline 385 & $0 \cdot 003$ & $1 \cdot 7$ & $25 \cdot 40$ & $26 \cdot 80$ & $43 \cdot 10$ & Serotransferrin precursor & gi|296490958 & 79783 & $7 \cdot 13$ & 40 & 7 & 50 & 767 \\
\hline 387 & $<0 \cdot 001$ & $3 \cdot 7$ & $10 \cdot 90$ & $8 \cdot 35$ & $30 \cdot 50$ & $\begin{array}{l}\text { Immunoglobulin mu heavy chain } \\
\text { constant region }\end{array}$ & gi|162424563 & 52881 & $5 \cdot 15$ & 26 & 8 & 35 & 658 \\
\hline 390 & $<0 \cdot 001$ & $2 \cdot 0$ & $51 \cdot 30$ & $30 \cdot 00$ & $59 \cdot 50$ & Ig heavy chain $\mathrm{C}$ region & gi|109029 & 34327 & $6 \cdot 07$ & 19 & 5 & 45 & 490 \\
\hline 391 & $<0 \cdot 001$ & $2 \cdot 7$ & $16 \cdot 10$ & $12 \cdot 80$ & $34 \cdot 30$ & $\begin{array}{l}\text { Immunoglobulin mu heavy chain } \\
\text { constant region }\end{array}$ & gi||162424563 & 52881 & $5 \cdot 15$ & 24 & 6 & 37 & 603 \\
\hline 392 & $0 \cdot 012$ & $1 \cdot 6$ & $37 \cdot 20$ & $36 \cdot 50$ & $56 \cdot 90$ & $\begin{array}{l}\text { Polymeric immunoglobulin re- } \\
\text { ceptor isoform } 1\end{array}$ & gi|426239425 & 83669 & $5 \cdot 79$ & 31 & 7 & 31 & 682 \\
\hline 393 & $0 \cdot 021$ & $1 \cdot 5$ & $3 \cdot 39$ & $22 \cdot 10$ & $33 \cdot 20$ & $\begin{array}{l}\text { Immunoglobulin gamma } 1 \text { heavy } \\
\text { chain constant region }\end{array}$ & gi|91982959 & 36562 & $6 \cdot 49$ & 7 & 2 & 15 & 197 \\
\hline 576 & $0 \cdot 036$ & 1.9 & $4 \cdot 01$ & $2 \cdot 11$ & $3 \cdot 27$ & Beta-casein & gi|49781319 & 11051 & $6 \cdot 71$ & 7 & 2 & 57 & 92 \\
\hline
\end{tabular}

$\dagger$ Number of peptides, matching the identified protein, whose sequence differs in at least one amino acid residue.

$\$$ Percentage of the identified protein sequence covered by the matched peptides.

SIdentification score obtained with the Mowse algorithm. A result is considered to be significant when a score above 92 is attained. 
Table 3. Spots showing differential expression between goat, sheep and cow milk whey samples $(P<0.05$ and fold change $>1 \cdot 5)$

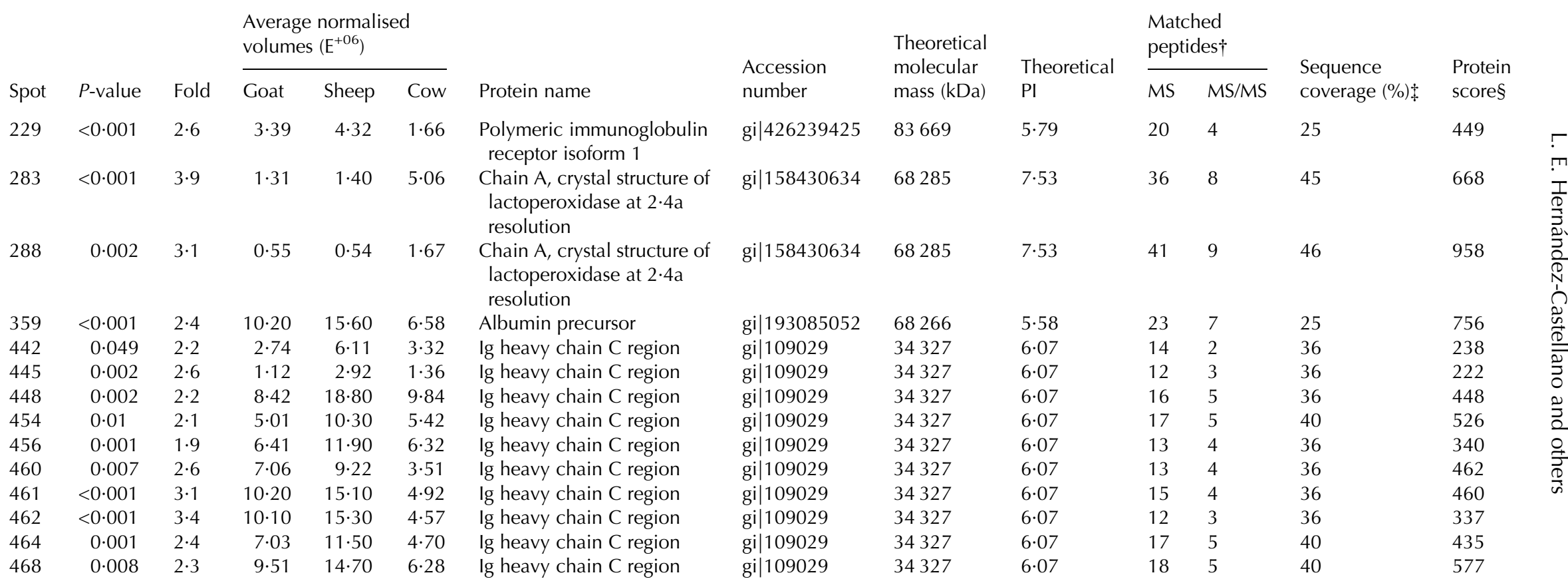

$\dagger$ Number of peptides, matching the identified protein, whose sequence differs in at least one amino acid residue.

$\$$ Percentage of the identified protein sequence covered by the matched peptides.

\$Identification score obtained with the Mowse algorithm. A result is considered to be significant when a score above 92 is attained. 
due to structural differences in the non-binding sites of the immunoglobulins, which would not be detected by ELISAbased methods, but it would influence the mass of the immunoglobulin fragment and therefore affect the results in the proteomics approach. Furthermore, the proteomics analysis leads to a much more refined analysis than one allowed by the ELISA analysis. The absence of differences from other non-immune proteins in colostrum could be due to the high concentration of Ig that could mask the presence of other less abundant proteins. Presently, several depletion kits for high abundance proteins removal are available, although their use has generated some controversy (HernándezCastellano et al. 2014b). In agreement with this statement, Golinelli et al. (2011) observed that the treatment with the Albumin and IgG removal kit was ineffective in removing IgG and BSA from the bovine colostrum whey. It is known that the albumin and IgG removal kit contains agaroseimmobilised anti-lgG against human proteins. The failure of these antibodies to capture the IgG present in bovine colostrum whey could be ascribed to a lack of cross reactivity of the antibodies to the bovine proteins.

In addition to the proteins described above, serotransferrin was also detected in the three studied species, although cow colostrum whey showed the highest value $(2.8$ and 1.9 fold change in spots 275 and 270, respectively). In agreement with these results, this protein has been also identified in cow (Yamada et al. 2002), sheep (Hernández-Castellano et al. 2015a) and goat colostrum (Fernandez et al. 2006). As described, the presence of this protein in colostrum is of high relevance to newborn ruminants as it plays a fundamental role in iron transport (Czesnikiewicz-Guzik et al. 2007b), explaining its immune activity against bacteria, fungi and viruses (Laporta et al. 2014). As described by Sanchez et al. (1988) this protein is found to be four times greater in cow colostrum than in mature or mastitic milk, suggesting a specific transport of this protein from blood into colostrum. Finally, serum albumin was less expressed in goat colostrum whey than sheep or cow colostrum whey. Even though this protein has no direct effect on the immune system, Wall et al. (2015) described that it can be used as a marker for the permeability of the blood-milk barrier and the transfer of other immune components such as lactate dehydrogenase.

Table 3 shows the differentially identified proteins in milk whey from the three studied ruminant species (goat, sheep and cow). As occurred with colostrum whey, the main differences between the three milk whey types are based on different immunoglobulins composition. Several differences were observed in the distribution of the IgG heavy chain $\mathrm{C}$ region, however, most of them showed higher intensity in sheep milk whey than the milk whey from the other two species. Another protein that was identified in milk whey was lactoperoxidase. The presence of this enzyme was higher in cow milk whey compared to sheep or goats. This protein is secreted by the mammary gland, participating in the oxidation of several products that have potent bactericidal activities.

The polymeric immunoglobulin receptor isoform 1 was found to be higher in sheep and goat whey compared to cow whey. This receptor binds polymeric $\lg \mathrm{A}$ and $\lg \mathrm{M}$ at the basolateral surface of epithelial cells. The complex is then transported across the cell to be secreted at the apical surface. During this process a cleavage occurs that separates the extracellular from the transmembrane segment. This protein has been described in cow milk by Smolenski et al. (2014) and in sheep milk by Ha et al. (2015), however, this is the first time that the presence of this protein has been observed in goat milk whey.

\section{Conclusions}

In conclusion, the differences observed in the chemical composition among different colostrums and milks could affect the final animal performance as a consequence of an unbalanced diet. Differences in the $\lg G$ and $\lg M$ content were observed between colostrum and milk from the three ruminant species studies, and several other differences were observed when the different proteomes were compared. Therefore, it seems that heterologous PIT could affect the final immune status of the animal or even lead to PIT failure, if the immune components of the selected colostrum or milk do not reach the requirements for the selected species. Further studies are necessary using more powerful proteomics and metabolomics techniques and other colostrum and milk fractions in other to have a broader overview of the differences between these two fluids among ruminant species.

Authors acknowledge the collaboration of Arturo Cabrera Hernández (Instituto Canario de Investigaciones Agrarias, Valle Guerra, Tenerife, Spain) and Braulio Granados Artiles (Compañía Canaria de Piensos S.A., Gran Canaria, Spain) during colostrum and milk samples collection as well as the collaboration of Sebastien Planchon (Luxembourg Institute of Science and Technology (LIST), Esch/Alzette, Luxembourg) in mass spectrometry protein identification. L. E. Hernández-Castellano acknowledges financial support from the Formación del Profesorado Universitario (FPU) programme (Ministry of Education, Madrid, Spain) and author A.M. Almeida acknowledges funding from the Science and Technology Foundation (Lisbon, Portugal). Authors are members of the COST action FA1002 - Proteomics in Farm Animals to whom networking funding is acknowledged.

AA, AMA, NC and LEHC conceived and designed the experiments. LEHC performed the experiments. LEHC, AMA and JR analysed the data. AA, AMA, NC and JR contributed reagents/materials/ analysis tools and LEHC, AMA, NC and AA wrote the paper.

\section{References}

Abd El-Fattah AM, Abd Rabo FH, El-Dieb SM \& El-Kashef HA 2012 Changes in composition of colostrum of Egyptian buffaloes and Holstein cows. BMC Veterinary Research $\mathbf{8} 19$

Almeida AM, Campos A, Francisco R, van Harten S, Cardoso LA \& Coelho AV 2010 Proteomic investigation of the effects of weight loss in the gastrocnemius muscle of wild and NZW rabbits via 2D-electrophoresis and MALDI-TOF MS. Animal Genetics 41 260-272

Álvarez S, Fresno $M$, Méndez P, Castro N, Fernández JR \& Sanz Sampelayo MR 2007 Alternatives for improving physical, chemical, 
and sensory characteristics of goat cheeses: the use of arid-land forages in the diet. Journal of Dairy Scencei 90 2181-2188

Banchero GE, Quintans G, Martin GB, Lindsay DR \& Milton JT 2004 Nutrition and colostrum production in sheep. 1. Metabolic and hormonal responses to a high-energy supplement in the final stages of pregnancy. Reproduction Fertility and Development 16 633-643

Banchero GE, Perez Clariget R, Bencini R, Lindsay DR, Milton JT \& Martin GB 2006 Endocrine and metabolic factors involved in the effect of nutrition on the production of colostrum in female sheep. Reproduction Nutrition Development 46 447-460

Boehmer JL, Bannerman DD, Shefcheck K \& Ward JL 2008 Proteomic analysis of differentially expressed proteins in bovine milk during experimentally induced escherichia coli mastitis. Journal of Dairy Science 91 4206-4218

Castro N, Capote J, Bruckmaier RM \& Argüello A 2011 Management effects on colostrogenesis in small ruminants: a review. Journal of Applied Animal Research 39 85-93

Curtain CC \& Fudenber HH 1973 Evolution of immunoglobulin antigens in ruminantia. Biochem Genet 8 301-308

Czesnikiewicz-Guzik M, Konturek SJ, Loster B, Wisniewska G \& Majewski S 2007a Melatonin and its role in oxidative stress related diseases of oral cavity. Journal of Physiology and Pharmacology58 (Suppl 3) 5-19

Czesnikiewicz-Guzik M, Loster B, Bielanski W, Guzik TJ, Konturek PC, Zapala J \& Konturek SJ 2007b Implications of oral Helicobacter pylori for the outcome of its gastric eradication therapy. Journal of Clinical Gastroenterology 41 145-151

Fernandez A, Ramos JJ, Loste A, Ferrer LM, Figueras L, Verde MT \& Marca MC 2006 Influence of colostrum treated by heat on immunity function in goat kids. Comparative Immunology and Microbiology 29 353-364

Golinelli LP, Conte CA, Paschoalin VMF \& Silva JT 2011 Proteomic analysis of whey from bovine colostrum and mature milk. Braz Ar-h Biol Techn 54 761-768

Ha M, Sabherwal M, Duncan E, Stevens S, Stockwell P, McConnell M, Bekhit AED \& Carne A 2015 In-depth characterization of sheep (Ovis aries) milk whey proteome and comparison with cow (Bos taurus). PLOS One 10

Hernández-Castellano LE, Morales-delaNuez A, Moreno-Indias I, Torres A, Sánchez-Macías D, Capote J, Castro N \& Argüello A 2013a Carcass and meat quality determination as a tool to promote local meat consumption in outermost regions of Europe. Journal of Applied Animal Research $\mathbf{4 1}$ 269-273

Hernández-Castellano LE, Morales-delaNuez A, Moreno-Indias I, Torres A, Sánchez-Macías D, Martell-Jaizme D, Capote J, Castro N \& Argüello A $2013 \mathrm{~b}$ Sensory analysis as a tool to compare imported and local meat in outermost regions of Europe. Journal of Applied Animal Research $\mathbf{4 1}$ 121-124

Hernández-Castellano LE, Almeida A, Ventosa M, Coelho A, Castro N \& Argüello A 2014a The effect of colostrum intake on blood plasma proteome profile in newborn lambs: low abundance proteins. BMC Veterinary Research 1085

Hernández-Castellano LE, Almeida AM, Castro N \& Argüello A 2014b The colostrum proteome, ruminant nutrition and immunity: a review. Current Protein and Peptide Science 15 64-74

Hernández-Castellano LE, Argüello A, Almeida AM, Castro N \& Bendixen E 2015a Colostrum protein uptake in neonatal lambs examined by descriptive and quantitative liquid chromatography-tandem mass spectrometry. Journal of Dairy Science $\mathbf{9 8}$ 135-147

Hernández-Castellano LE, Morales-delaNuez A, Sánchez-Macías D, Moreno-Indias I, Torres A, Capote J, Argüello A \& Castro N 2015b The effect of colostrum source (goat vs. sheep) and timing of the first colostrum feeding ( $2 \mathrm{~h}$ vs. $14 \mathrm{~h}$ after birth) on body weight and immune status of artificially reared newborn lambs. Journal of Dairy Science $\mathbf{9 8}$ 204-210

Hernández-Castellano LE, Moreno-Indias I, Morales-delaNuez A, SánchezMacías D, Torres A, Capote J, Argüello A \& Castro N 2015c The effect of milk source on body weight and immune status of lambs. Livestock Science 175 70-76
Hernández-Castellano LE, Suárez-Trujillo A, Martell-Jaizme D, Cugno G, Argüello A \& Castro N 2015d The effect of colostrum period management on BW and immune system in lambs: from birth to weaning. Animal 9 1672-1679

Hurley WL \& Theil PK 2011 Perspectives on immunoglobulins in colostrum and milk. Nutrients 3 442-474

Institut National de la Recherche Agronomique (INRA) 2007 Alimentation des Bovins, Ovins et Caprins. Editions Quae. Paris

James BD, Bakalova M, Liesegang J, Reiff WM, Skelton BW \& White AH 2001 Isolation and detailed characterization of the trans- $[(\mathrm{H} 2 \mathrm{O})$ $2 \mathrm{FeCl} 4]_{(-)}$anion: stabilization of novel iron(III) species by large organic cations. Inorganic Chemistry 40 4617-4622

Laporta J, Gross JJ, Crenshaw TD, Bruckmaier RM \& Hernandez LL 2014 Short communication: timing of first milking affects serotonin (5-HT) concentrations. Journal of Dairy Science 97 2944-2948

Lérias J, Hernández-Castellano L, Morales-delaNuez A, Araújo S, Castro N, Argüello A, Capote J \& Almeida A 2013 Body live weight and milk production parameters in the Majorera and Palmera goat breeds from the Canary Islands: influence of weight loss. Tropical Animal Health and Production 45 1731-1736

Lérias JR, Hernández-Castellano LE, Suárez-Trujillo A, Castro N, Pourlis A \& Almeida AM 2014 The mammary gland in small ruminants: major morphological and functional events underlying milk production - a review. Journal of Dairy Research 81 304-318

Morales-delaNuez A, Moreno-Indias I, Sánchez-Macías D, Capote J, Juste MC, Castro N, Hernández-Castellano LE \& Argüello A 2011 Sodium dodecyl sulfate reduces bacterial contamination in goat colostrum without negative effects on immune passive transfer in goat kids. Journal of Dairy Science 94 410-415

Moreno-Indias I, Sánchez-Macías D, Castro N, Morales-delaNuez A, Hernández-Castellano LE, Capote J \& Argüello A 2012 Chemical composition and immune status of dairy goat colostrum fractions during the first $10 \mathrm{~h}$ after partum. Small Ruminant Research 103 220-224

Park YW, Juárez M, Ramos M \& Haenlein GFW 2007 Physico-chemical characteristics of goat and sheep milk. Small Ruminant Research $\mathbf{6 8}$ $88-113$

Printz B, Sergeant K, Guignard C, Renaut J \& Hausman JF 2013 Physiological and proteome study of sunflowers exposed to a polymetallic constraint. Proteomics 13 1993-2015

Sanchez L, Aranda P, Perez MD \& Calvo M 1988 Concentration of lactoferrin and transferrin throughout lactation in cow's colostrum and milk. Biological Chemistry Hoppe Seyler 369 1005-1008

Smolenski GA, Broadhurst MK, Stelwagen K, Haigh BJ \& Wheeler TT 2014 Host defence related responses in bovine milk during an experimentally induced Streptococcus uberis infection. Proteome Science 1219

Stelwagen K, Carpenter E, Haigh B, Hodgkinson A \& Wheeler TT 2009 Immune components of bovine colostrum and milk. Journal of Animal Science 87(Suppl 13) 3-9

Tabatabaei S, Nikbakht G, Vatankhah M, Sharifi H \& Alidadi N 2013 Variation in colostral immunoglobulin $G$ concentration in fat tailed sheep and evaluation of methods for estimation of colostral immunoglobulin content. Acta Veterinario Brno $\mathbf{8 2}$

Torres A, Castro N, Hernández-Castellano LE, Argüello A \& Capote J 2013 Effects of milking frequency on udder morphology, milk partitioning, and milk quality in 3 dairy goat breeds. Journal of Dairy Science $\mathbf{9 6}$ 1071-1074

Tsiligianni T, Dovolou E \& Amiridis GS 2012 Efficacy of feeding cow colostrum to newborn lambs. Livestock Science 149 305-309

Wall SK, Gross JJ, Kessler EC, Villez K \& Bruckmaier RM 2015 Bloodderived proteins in milk at start of lactation: indicators of active or passive transfer. Journal of Dairy Science 98 7748-7756

Yamada M, Murakami K, Wallingford JC \& Yuki Y 2002 Identification of low-abundance proteins of bovine colostral and mature milk using two-dimensional electrophoresis followed by microsequencing and mass spectrometry. Electrophoresis 23 1153-1160

Zhang L, Boeren S, Hageman JA, Van Hooijdonk T, Vervoort J \& Hettinga K 2015 Bovine milk proteome in the first 9 days: protein interactions in maturation of the immune and digestive system of the newborn. PLoS One 10 e0116710 